\title{
PENINGKATAN PRESTASI BELAJAR MATEMATIKA MELALUI PENDEKATAN DISCOVERY LEARNING SISWA KELAS V
}

\author{
Lestariningsih \\ SD Tulasan, Bambanglipuro, Bantul \\ ningsihlestari726@gmail.com
}

\begin{abstract}
Abstrak
Penelitian ini dilatarbelakangi adanya permasalahan yaitu rendahnya nilai matematika siswa khususnya pada materi menentukan skala. Penelitian bertujuan untuk mendeskripsikan proses pelaksanaan pembelajaran dengan menggunakan pendekatan discovery learning di kelas V SD Tulasan dan untuk meningkatkan prestasi belajar matematika siswa kelas V SD Tulasan menggunakan pendekatan discovery learning. Metode yang digunakan dalam penelitian ini adalah Penelitian Tindakan Kelas yang dilaksanakan 2 siklus. Tiap siklus terdiri dari 2 pembelajaran. Tiap siklus dalam Penelitian Tindakan Kelas terdiri atas kegiatan perencanaan, pelaksanaan, observasi, dan refleksi. Subjek penelitian adalah siswa kelas V SD Tulasan yang berjumlah 24 siswa, terdiri dari 13 siswa laki-laki, dan 11 siswa perempuan. Teknik analisis datanya adalah kualitatif. Hasil penelitian menunjukkan bahwa penggunaan pendekatan discovery learning dapat meningkatkan prestasi belajar siswa kelas V SD Tulasan. Sebelum penelitian, persentase pencapaian KKM untuk hasil tes anak adalah $50 \%$. Setelah penelitian siklus I menjadi 71\%, sedangkan setelah siklus II mencapai $88 \%$. Penelitian ini telah mencapai target yang diharapkan yaitu dapat mencapai KKM dengan tingkat pencapaian minimal 75\%.
\end{abstract}

Kata kunci : prestasi belajar, matematika, pendekatan discovery learning

\section{PENDAHULUAN}

Pendidikan memegang peranan penting terhadap kemajuan suatu Negara. Saat ini seharusnya telah terjadi perubahan yang universal dari belajar sebagai suatu poses transmisi pengetahuan menjadi belajar mengkonstruk pengetahuan. Sebagaimana dikemukakan oleh Sembiring, (2010:41) bahwa dalam proses transmisi pengetahuan, siswa hanya mendengarkan penjelasan guru. Proses pembelajaran ini sangat menjemukan dan siswa sulit dalam memahami konsep-konsep matematika. Pandangan tentang pembelajaran tersebut harus diganti dengan proses pembelajaran dimana siswa aktif mengkonstruk pengetahuan. Guru sebagai fasilitator akan membantu siswa dalam proses pembelajaran.

Membelajarkan anak didik menjadi tantangan guru. Guru tidak hanya mengajar, tetapi harus dapat membelajarkan anak didik agar dapat belajar menemukan konsep-konsep keilmuan.. Guru harus dapat mengemas kegiatan pembelajaran menjadi pembelajaran yang menyenangkan sehingga siswa dapat memahami yang pelajari.
Kurikulum yang berlaku saat ini adalah kurikulum 2013. Kurikulum ini mengharuskan pembelajaran secara tematik integratif. Hal ini sesuai dengan tahap perkembangan anak usia SD yang masih berpikir holistik. Berpikir holistik yaitu berpikir secara menyeluruh sebagai suatu kesatuan, lebih diutamakan daripada hanya memahami bagian-bagiannya sebagai upaya untuk memahami secara menyeluruh.

Kegiatan pembelajaran dilakukan dengan mengutamakan proses pembelajaran dari pada hasilnya. Diharapkan dengan proses yang bagus akan menghasilkan out put yang bagus. Guru dituntut dapat menciptakan proses pembelajaran yang dapat mendorong keaktifan anak serta anak dapat menemukan konsep kegiatan pembelajaran. Sebagian besar guru masih menggunakan motode konvensional, dimana pembelajaran didominasi guru. Guru menyampaikan materi, siswa mendengarkan dan mencatat, kemudian mengerjakan soal latihan. Dengan cara ini siswa menjadi jenuh dengan pembelajaran. Hal ini terlihat 
ketika guru menjelaskan, anak ada yang berbicara dan bermain dengan teman.

Situasi yang demikian menjadikan pembelajaran matematika kurang mendapat perhatian dari siswa, sehingga nilai matematika relatif lebih rendah dari KKM. Hal ini terjadi pada siswa kelas V SD Tulasan. Terbukti bahwa nilai ulangan pada muatan pelajaran matematika pada materi menentukan skala masih terdapat 50\% siswa yang nilainya di bawah KKM. Keadaan yang demikian mengharuskan guru melakukan tindakan yang dapat memperbaiki proses pembelajaran. Perbaikan proses pembelajaran diharapkan dapat meningkatkan prestasi belajar anak khususnya pada muatan pelajaran matematika.

Penerapan pembelajaran HOTS dengan discovery learning diharapkan mampu meningkatkan kualitas pembelajaran serta meningkatkan hasil belajar siswa, baik kognitif, afktif, maupun psikomotorik. Model pembelajaran penemuan (discovery learning) diartikan sebagai proses pembelajaran yang terjadi ketika siswa tidak disajikan informasi secara langsung tetapi dituntut untuk mengorganisasikan pemahaman mengenai informasi tersebut secara mandiri. Siswa dilatih terbiasa menjadi seorang yang saintis (ilmuan). Anak-anak diharapkan pula bisa berperan aktif. Salah satu pendekatan yang dapat digunakan dalam pembelajaran adalah pendekatan saintifik, yaitu pendekatan yang menggunakan langkah-langkah serta kaidah ilmiah dalam proses pembelajaran. Langkah ilmiah yang diterapkan meliputi menemukan masalah, merumuskan masalah, mengajukan hipotesis, mengumpulkan data, menganalisis data, dan menarik kesimpulan (Daryanto, 2014: 51).

Menurut Hosnan (2014:282), discovery learning adalah model untuk mengembangkan cara belajaraktifdengan menemukan sendiri, menyelidiki sendiri, maka hasil yang diperoleh akan setia dan tahan lama dalam ingatan. Siswa bisa belajar berpikir analisis dan mencoba memecahkan sendiri masalah.. Karakteristik discovery learning adalah (1) mengeksplorasi dan memecahkan masalah untuk menciptakan, mengabungkan, dan menggeneralisasi pengetahuan; (2) berpusat pada siswa; (3) kegiatan untuk menggabungkan pengetahuan baru dan pengetahuan yang sudah ada.

Adapun sintaks yang harus dilaksanakan yaitu : (Ariyana, dkk,2019:35) pemberian rangsang (stimulation), pernyataan/identifikasi masalah (problem statement), pengumpulan data (data collection), pengolahan data (data processing), pembuktian (verification), dan menarik kesimpulan (generalization).

Menurut Suprihatiningrum (2014:244), terdapat dua cara dalam pembelajaran penemuan (discoverylearning), yaitu: Pembelajaran penemuan bebas (free discovery learning) yakni pembelajaran penemuan tanpa adanya petunjuk atau arahan dan Pembelajaran penemuan terbimbing (guided discovery learning) yakni pembelajaran yang membutuhkan peran guru sebagai fasilitator..

Sedangkan menurut Kurniasih, dkk (2014:64-65), metode discovery learning juga memiliki beberapa kelemahan, antara lain menimbulkan asumsi bahwa ada kesiapan pikiran untuk belajar. Bagi siswa kurang pandai, akan mengalami kesulitan abstrak dalam mengungkapkan hubungan antara konsep- konsep tertulis atau lisan, sehingga menimbulkan frustasi. Metode ini tidak efisien karena membutuhkan waktu yang lama. Pengajaran ini lebih cocok untuk mengembangkan pemahaman, sedangkan mengembangkan aspek konsep, keterampilan dan emosi kurang mendapat perhatian.

Hal inilah yang mendorong peneliti untuk melakukan penelitian tentang penerapan pembelajaran matematika melalui pendekatan pembelajaran discovery learning dengan tujuan untuk peningkatan prestasi belajar siswa pada muatan pelajaran Matematika di SD Tulasan.. Penelitian ini dilakukan melalui Penelitian Tindakan Kelas (PTK).

\section{METODE PENELITIAN}

Penelitian ini merupakan penelitian tindakan kelas yang berfokus pada peningkatan prestasi belajar muatan pelajaran Matematika 
dengan menggunakan pendekatan pembelajaran discovery learning di SD Tulasan.

Penelitian dilaksanakan pada bulan Januari hingga Maret 2020 tahun ajaran 2019/2020. Subjek penelitian adalah siswa kelas V SD Tulasan, Bambanglipuro, Bantul sebanyak 24 orang, terdiri dari 13 anak laki-laki dan 11 anak perempuan. SD Tulasan terletak di Dusun Tulasan RT 03 Desa Mulyodadi, Kecamatan Bambanglipuro, Kabupaten Bantul, DIY. Peneliti memilih tempat tersebut karena peneliti adalah guru di sekolah tersebut. Jadi peneliti mengetahui tentang permasalahan yang terjadi di sekolah tersebut.

Prosedur penelitian dilaksanakan dengan mengikuti alur PTK yang telah dietetapkan, yaitu terdiri dari perencanaa, pelaksanaan, observasi, dan refleksi. Teknik pengumpulan data dilakukan melalui observasi, tes, dan dokumentasi. Instrumen yang digunakan adalah lembar observasi aktivitas guru dalam pembelajaran, lembar observasi aktivitas siswa dalam pembelajaran, dan soal tes. Teknik analisis data yang digunakan adalah diskriptif atau kualitatif.

\section{HASIL PENELITIAN DAN PEMBAHASAN}

Pembelajaran dengan menggunakan pendekatan discovery learning diterapkan pada siswa kelas V SD Tulasan, Bambanglipuro, Bantul dengan tujuan meningkatkan hasil belajar matematika siswa. Sebelum dilakukan kegiatan PTK bersiklus, peneliti melakukan kegiatan diskusi dengan kolaborator mengenai kegiatan yang akan dilakukan dan menyusun perangkat pembelajaran serta instrumen penelitian. Perangkat pembelajaran yang disusun berupa RPP,alat dan media pembelajaran. Instrumen yang disusun berupa soal tes, lembar observasi aktivitas guru dan lembar observasi aktivitas siswa.

\section{Deskripsi Siklus I}

Siklus I dilaksanakan dalam 2 kali pertemuan, yaitu tanggal 13 Februari 2020 dan 20 Februari 2020. Pertemuan I diawali dengan kegiatan perencanaan meliputi kegiatan menyusun RPP, alat peraga/media, Lembar Kerja Peserta Didik, dan Lembar Pengamatan/observasi.

Kegiatan yang kedua adalah pelaksanaan pembelajaran. Kegiatan awal dimulai dengan salam, menanyakan kabar, mengecek kehadiran siswa, dilanjutkan dengan do'a dipimpin oleh salah seorang siswa. Mengulas sedikit materi yang telah disampaikan hari sebelumnya. Kegiatan awal diakhiri dengan menyampaikan tujuan pembelajaran

Kegiatan inti pada muatan pelajaran matematika dimulai membentuk kelompok yang terdiri 4 anak. Guru memberikan stimulus gagasan dan motivasi peserta didik dengan menyajikan gambar dan melakukan tanya jawab dengan peserta didik. Guru meminta peserta didik mengungkapkan pendapatnya tentang pengamatan gambar. Guru membangun suasana belajar yang menantang dengan pendekatan interaktif. Guru memberikan beberapa pertanyaan kepada pada setiap kelompok. Jawaban peserta didik sebagai media untuk mengetahui seberapa jauh peserta didik bertanggung jawab atas kelompoknya.

Guru memberikan kesempatan pada peserta didik untuk melakukan identifikasi permasalah dan menentukan solusi pemecahannya yaitu dengan cara tanya jawab antara guru dan peserta didik. Siswa kemudian membuat catatan penting hasil pengamatan mengukur skala gambar. Guru memberikan tugas pada peserta didik untuk menemukan contoh lain dengan membaca buku, mencari di internet, wawancara, atau sumber lain tentang cara menentukan skala. Siswa mencatat hasil dari membaca buku atau menjelajah internet tentang skala.

Informasi yang didapatkan pada diskusi peserta didik, diolah, diklasifikasikan, ditabulasi sehingga siswa akan memperoleh pengalaman dan pengetahuan baru tentang bagaimana menentukan skala.

Secara bergantian tiap kelompok dengan penuh tanggung jawab, keberanian, rasa percaya diri, dan rasa cinta tanah air mempresentasikan hasil kerja kelompoknya. Secara bergantian, tiap kelompok menanggapi hasil kerja kelompok 
lain (mengajukan pertanyaan, menyanggah, dan mengajukan usul).

Siswa bersama guru akan membuat simpulan hasil belajar. Kesimpulan tersebut dapat mengukur seberapa jauh siswa memahami dan menguasi materi pembelajaran. Kegiatan pembelajaran diakhiri dengan menyimpulkan kegiatan pembelajaran yang dilakukan, menyanyikan salah satu lagu daerah untuk menumbuhkan Nasionalisme, Persatuan, dan Toleransi, dan do'a penutup di pimpin oleh salah satu siswa.

Kegiatan observasi dilakukan oleh peneliti dan kolaborator. Pada dasarnya ketika kegiatan pembelajaran dimulai, anak sudah tertarik dengan alat dan bahan pembelajaran yang akan digunakan oleh guru. Hal ini terlihat ketika guru masuk kelas dengan membawa meteran. Dalam mengerjakan tugas kadang anak masih ragu. Terlihat masih ada yang maju menanyakan kepada guru bagaimana seharusnya mengerjakannya. Ada beberapa siswa yang belum dapat mengumpulkan tugas tepat waktu.

Hasil observasi akivitas guru mendapatkan skor 17 berarti nilainya $71 \%$. dalam kategori cukup. Pada kegiatan observasi diketahui gambaran tentang kelebihan maupun kekurangan selama pelaksanaan. Kelebihan yang diperoleh adalah sebagai berikut: 1) Guru sudah melaksanakan pembelajaran sesuai dengan rencana pelaksanaan pembelajaran yang telah dibuat; 2) Guru selalu memotivasi peserta didik selama pembelajaran berlangsung agar siswa bersemangat dalam mengikuti kegiatan pembelajaran; 3) Guru sudah menggunakan media yang menarik yaitu benda yang biasa digunakan sehari-hari. Selain kelebihan, terdapat kekuarangan diantaranya : 1) Guru belum memberikan arahan pelajaran selanjutnya; 2) Guru belum memberikan kesempatan untuk anak berpikir kritis; 3) Guru belum melibatkan seluruh siswa dalam kegiatan pembelajaran; 4) Guru belum melakukan evaluasi.

Hasil observasi aktifitas siswa mendapatkan skor 17 yang berarti nilainya $71 \%$ dalam kategori cukup. Pada kegiatan observasi aktifitas siswa, diketahui gambaran kelebihan maupun kekurangan selama pelaksanaan kegiatan pembelajaran.
Kelebihan yang diperoleh adalah: 1) Siswa mulai tertarik dengan kegiatan yang dilakukan. Hal ini ditunjukkan dengan sikap antusias siswa menyelesaikan tugas yang diberikan; 2) Komunikasi antara siswa dan guru terjalin dengan baik. Siswa tidak takut untuk bertanya kepada guru, dan guru selalu menanggapi pertanyaan peserta didik dengan baik.

Adapun kekurangan-kekurangan yang tampak dari aktivitas peserta didik saat pelaksanaan pembelajaran adalah: 1) Kesiapan siswa dalam mengikuti pembelajaran belum menyeluruh. Hal ini terlihat bahwa masih ada anak yang belum langsung siap dengan kegiatan pembelajaran; 2) Belum semua anak aktif dalam kelompoknya.

Berdasarkan hasil observasi peneliti dan kolaborator selama proses tindakan pembelajaran dan tes prestasi belajar Matematika siswa, diperoleh gambaran tentang tindakan kelas yang dilaksanakan dalam pertemuan pertama siklus I. Hasil observasi dan analisis selama dan setelah tindakan kelas pertemuan pertama siklus I ini disusun berdasarkan pada temuan-temuan di lapangan, kemudian didiskusikan oleh peneliti dan kolabolator.

Aspek keberhasilan pelaksanaan tindakan pada siklus Iadalah sebagai berikut:(1)Pembelajaran berlangsung secara aktif. Guru memberikan masalah kemudian siswa dengan aktif menyelesaikan permasalahan tersebut melalui kegiatan yang nyata, yaitu mengukur luas lapangan. (2) Secara umum peserta didik sudah menunujukkan partisipasi aktif dalam proses pembelajaran, walaupun masih memerlukan petunjuk dan bimbingan dari guru. Adapun kekurangan-kekurangan yang tampak dari aktivitas peserta didik saat pelaksanaan pembelajaran adalah: (1) Kesiapan siswa dalam mengikuti pembelajaran belum menyeluruh. (2) Belum semua siswa ikut aktif dalam kegiatan pembelajaran. Dalam kegiatan diskusi kelompok, ada anak yang belum aktif dalam kelompoknya. (3) Ketika guru memberikan umpan balik, tidak semua siswa memperhatikan. Berdasarkan refleksi siklus I pertemuan I di atas, maka dilakukan perbaikan pada siklus I pertemuan II. Kegiatan siklus I pertemuan II diawali dengan perencanaan 
yaitu menyiapkan RPP, alat peraga/media, Lembar Kerja Peserta Didik, dan Lembar Pengamatan/ observasi. selanjudnya pembelajatran diawali dengan doa, salam, dan menanyakan kabar serta mengecek kehadiran siswa. Untuk memupuk rasa nasionalis, dilanjutkan menyanyikan lagu Indonesia Raya. Kemudian mengulas sedikit materi yang telah disampaikan sebelumnya serta menyampaikan tujuan pembelajaran hari ini.

Pada pertemuan 2 siklus I, peneliti menambah media pembelajaran berupa video cara menentukan skala. Sebelum memulai kegiatan kelompok, siswa melihat tayangan video. Terjadilah tanya jawab tentang video yang ditayangakan

Kegiatan dilanjutkan dengan pembagian kelompok. Siswa dibagi menjadi 6 kelompok tiap kelompok terdiri 4 anak. Siswa memperhatikan petunjuk dalam pengerjaan tugas. Tugas kelompok diawali dengan membaca permasalahan yang ada pada LKPD, kemudian siswa melakukan kegiatan mengukur sesuai petunjuk pada lembar kerja. Siswa mengukur benda yang sudah disediakan guru pada masing-masing kelompok, sehingga akan ditemukan berapa panjangnya. Siswa segera diarahkan untuk keluar kelas menuju ke lapangan. lapangan berbentuk persegi. Siswa disuruh untuk mengukur salah satu sisi dari lapangan. Siswa memperoleh jawaban bahwa panjang satu sisi dari lapangan adalah $45 \mathrm{~m}$. Untuk menentukan skala anak-anak perlu mengubah satuan meter ke dalam $\mathrm{cm}$. Guru bertanya 1 meter ada berapa $\mathrm{cm}$. Siswa diberikan alat untuk mengukur dan menunjukkan panjang 1 meter. Kemudian siswa dapat menjawab bahwa $1 \mathrm{~m}=100 \mathrm{~cm}$. Panjang satu sisi lapangan tersebut adalah $45 \mathrm{~m}$, sehingga diperoleh hasil $45 \mathrm{~m}$ $=4.500 \mathrm{~cm}$. Jika panjang pada denah $15 \mathrm{~cm}$, maka cara menentukan skala adalah panjang pada peta dibagi panjang sebenarnya. Jika nanti siswa akan membuat denah maka, $1 \mathrm{~cm}$ akan mewakili $300 \mathrm{~cm}$ panjang sebenarnya. Untuk mengetahui kebenaran apa yang siswa kerjakan, maka dilakukan diskusi kelas, kemudian siswa mengerjakan soal evaluasi.

Kegiatan pembelajaran diakhiri dengan menyanyikan salah satu lagu daerah untuk menumbuhkan nasionalisme, persatuan, dan toleransi. Kemudian guru menyampaikan gambaran tentang apa yang akan dipelajari pada pembelajaran selanjutnya, dilajutkan kemudian doa penutup dan salam.

Pada kegiatan pembelajaran pertemuan 2 siklus I ini, anak anak lebih siap dibanding sebelumnya. Anak anak sangat antusis dengan kegiatan yang akan dilakukan. Hal ini terlihat ketika guru masuk kelas membawa alat ukur anakanak bersorak sorai tanda senang akan melakukan kegiatan mengukur.

Siswa secara aktif mengikuti kegiatan pembelajaran dengan melakukan praktek mengukur. Pada kelompok I didominasi oleh SZA. Dia sangat aktif dalam mengukur dan mengamati setiap kegiatan. Berbeda dengan TNP, Ia lebih banyak diam dalam melakukan kegiatan mengukur. Ia juga belum bisa menyebutkan satuan ukuran yang digunakan untuk mengukur.

Hasil observasi akifitas guru mendapatkan skor 20 nilainya $83 \%$. dalam kategori baik. Pada kegiatan observasi ini diketahui gambaran tentang kelebihan maupun kekurangan selama pelaksanaan kegiatan pembelajaran. Kelebihan dalam kegiatan pembelajaran ini adalah : 1) Guru telah memberikan pembelajaran sesuai tahapan kegiatan pendekatan discovery Learning. 2) Suasana pembelajaran yang cukup menyenangkan karena siswa dengan aktif melakukan kegiatan mengukur dan memecahkan masalah sesuai dalam lembar kerja. 3) Guru telah memberikan koreksi berupa umpan balik dari satiap hasil penugasan yang dibuat oleh peserta didik. 4) Guru memberika reward bagi peserta didik yang berhasil menyelesaikan masalah dengan baik dan benar. Reward tersebut berupa pujian. Dengan pujian diharapkan peserta didik menjadi lebih bersemangat dalam mengikuti pembelajaran. Selain kelebihan, terdapat kekuarangan diantaranya :1) Guru sulit untuk menumbuhkan anak untuk dapat berfikir berpikir kritis. 2) Guru belum melibatkan seluruh siswa dalam kegiatan pembelajaran

Hasil observasi aktivitas siswa mendapatkan skor 20, nilainya $83 \%$ dalam kategori baik. Pada kegiatan observasi aktifitas siswa ini diketahui gambaran tentang kelebihan maupun kekurangan 
selama pelaksanaan kegiatan pembelajaran. Kelebihan yang diperoleh adalah 1) Anak lebih siap mengikuti pembelajaran. 2) Peserta didik dengan bimbingan guru bersama-sama melakukan refleksi atas apa yang sudah dilakukan selama pembelajaran. Kegiatan siklus I ditutup dengan mengerjakan evaluasi.

Tes atau evaluasi dilakukan untuk mengetahui keberhasilan pembelajaran dengan pendekatan discovery learning.

Nilai hasil tes pada siklus I dapat dilihat pada tabel 1 berikut!

Tabel 1. Nilai Tes Siswa Siklus I

\begin{tabular}{clccc}
\hline No & Nama & Nilai & KKM & Keterangan \\
\hline 1 & AMA & 80 & & Tuntas \\
2 & ADF & 75 & & Tuntas \\
3 & AES & 70 & & Belum tuntas \\
4 & DAS & 70 & Tuntas \\
5 & DP & 80 & Tuntas \\
6 & EYP & 70 & Belum tuntas \\
7 & FAS & 95 & & Tuntas \\
8 & FRM & 70 & & Belum tuntas \\
9 & FBS & 75 & 75 & Tuntas \\
10 & FDES & 85 & & Belum tuntas \\
11 & GG & 80 & & Tuntas \\
12 & GJE & 70 & & Belum tuntas \\
13 & HNH & 90 & Tuntas \\
14 & HSD & 90 & Tuntas \\
15 & JH & 75 & Tuntas \\
16 & KS & 80 & Tuntas \\
17 & MSA & 90 & Tuntas \\
18 & MANA & 80 & Tuntas \\
19 & NAU & 70 & Belum tuntas \\
20 & RDA & 85 & Tuntas \\
21 & RRZGA & 90 & Tuntas \\
22 & SZA & 95 & Tuntas \\
23 & TP & 70 & Belum tuntas \\
24 & YSM & 75 & Tuntas \\
\hline & & &
\end{tabular}

Berdasarkan tabel di atas, diketahui bahwa masih ada 7 anak yang belum tuntas, sehingga diperlukan tindakan untuk siklus yang kedua.

Berdasarkan hasil observasi peneliti dan kolaborator selama proses tindakan pembelajaran dan tes prestasi siswa, diperoleh gambaran tentang tindakan kelas yang dilaksanakan dalam pembelajaran 2 siklus I. Hasil observasi dan analisis disusun berdasarkan pada temuan-temuan di lapangan yang kemudian didiskusikan oleh peneliti dan kolabolator.

Aspek keberhasilan pelaksanaan tindakan pada siklus I adalah: (1) Pembelajaran berlangsung secara aktif. Siswa sangat senang dengan kegiatan pembelajaran karena berhasil memecahkan masalah. (2) Siswa sangat menyukai pendekatan yang digunakan dalam pembelajaran. Hal ini ditunjukkan dengan peserta didik yang cukup antusias berusaha menyelesaikan permasalahanpermasalahan yang diberikan. Peserta didik juga cukup antusias memanfaatkan media belajar yang telah disediakan.

Aspek kelemahan pelaksanaan tindakan pada pertemuan ke 2 siklus I adalah: (1) Pemantauan guru dalam menghadapi anak yang mengalami kesulitan dalam mengukur masih belum menyeluruh. (2) Ada sebagian siswa yang masih belum fokus walaupun sudah berulangkali diingatkan. (3) Siswa belum sepenuhnya terbiasa dengan tahap-tahap pembelajaran discovery learning.

Persentase prestasi belajar siswa matematika yang telah tuntas sebesar $71 \%$ atau sebanyak 17 siswa. Prestasi anak yang belum tuntas sebesar $39 \%$ yaitu sebanyak 7 siswa. Hal ini menunjukkan persentase peserta didik yang tuntas masih di bawah kriteria keberhasilan yang ditetapkan yaitu 75\% dari jumlah siswa.

\section{Deskripsi Siklus II}

Kegiatan penelitian dilanjutkan untuk siklus yang ke-2. Siklus II dilaksanakan dalam 2 kali pertemuan, yaitu tanggal 5 Maret dan 12 Maret 2020. Pertemuan I siklus II diawali dengan perencanaan yaitu menyusun RPP, alat peraga/ media, Lembar Kerja Peserta Didik, dan Lembar Pengamatan/observasi.

Kegiatan diawali dengan salam, dan mengecek kehadiran siswa, dilanjutkan dengan do'a dipimpin oleh salah seorang siswa. Mengulas sedikit materi yang telah disampaikan hari sebelumnya dan menyampaikan tujuan pembelajaran. Kegiatan inti 
dimulai dengan siswa melihat video pembelajaran tentang menentukan skala. Terjadilah tanya jawab tentang kegiatan menentukan skala. Kemudian siswa dibagi menjadi 6 kelompok, masing-masing terdiri atas 4 anak. Guru membagikan LKPD. Tiap kelompok mencermati LKPD kemudian menyelesaikannya permasalahan tentang cara menentukan skala.

Untuk siklus II siswa tidak hanya menentukan Panjang sebenarnya tetapi juga lebar sebenarnya. Panjang taman sekolah tersebut $5 \mathrm{~cm}$ dan lebarnya $4 \mathrm{~cm}$. Skala pada peta tersebut $1: 400$. Panjang taman pada gambar $=5 \mathrm{~cm}$. Panjang taman $=$ panjang denah : skala $=5: 1$ per $40=5 \times 400=$ 2000. Jadi panjang taman sebenarnya adalah 2000 $\mathrm{cm}$ atau $20 \mathrm{~m}$. Lebar taman pada gambar $=4 \mathrm{~cm}$. lebar denah : skala sama dengan 4: 1 per 400 sama dengan 4 x 400 sama dengan $1600 \mathrm{~cm}$ atau $16 \mathrm{~m}$. Jadi Lebar taman sebenarnya adalah $1600 \mathrm{~cm}$ atau $16 \mathrm{~m}$.

Kegiatan pembelajaran diakhiri dengan menyimpulkan kegiatan pembelajaran yang dilakukan,

Observasi pada pertemuan pertama siklus II dilakukan oleh peneliti maupun kolaborator. Saat kegiatan dimulai, anak-anak tampak lebih gembira karena mereka akan melakukan kegiatan mengukur lagi. Anak lebih siap mengikuti pembelajaran dari pada siklus sebelumnya. Kegiatan dimulai dengan melihat video pembelajaran sehingga menambah semangat anak-anak untuk mengikuti kegiatan pembelajaran. Pada pertemuan pertama siklus II ini anak sudah tidak banyak bertanya pada guru tentang apa yang harus dilakukan. Mereka segera membaca LKS dan melakukan kegiatan sesuai dengan yang ada pada LKS. Semua anak aktif dalam kelompoknya.

Hasil observasi akivitas guru mendapatkan skor 21 yang berarti nilainya $88 \%$ atau dalam kategori sangat baik. Pada kegiatan observasi ini diketahui gambaran tentang kelebihan maupun kekurangan selama pelaksanaan kegiatan pembelajaran. Kelebihan yang diperoleh adalah: (1) Kegiatan pembelajaran sudah dilakukan sesuai dengan rencana pelaksanaan pembelajaran yang telah dibuat. (2) Guru selalu memotivasi peserta didik selama pembelajaran berlangsung agar siswa bersemangat dalam mengikuti kegiatan pembelajaran. (3) Guru sudah menggunakan media yang menarik karena media lingkungan sekitar. (4) Guru menggunakan media LCD yang digunakan untuk menampilkan video cara menentukan skala.

Selain kelebihan tersebut, terdapat kekuarangan yaitu guru belum mampu melibatkan semua siswa dalam pembelajarn. Hal ini terlihat ketika masih ada siswa yang belum memperhatikan ketika guru memberikan refleksi pembelajaran. Pada pertemuan pertama siklus II pertemuan I belum ada evaluasi pembelajaran.

Hasil observasi aktifitas siswa mendapatkan skor 21 yang berarti nilainya $88 \%$ atau dalam kategori sangat baik. Pada kegiatan observasi aktifitas siswa ini diketahui gambaran tentang kelebihan maupun kekurangan selama pelaksanaan kegiatan pembelajaran dilihat dari aktivitas siswa. Kelebihan yang diperoleh adalah: (1) Siswa sudah terkondisi dengan baik dan segera memposisikan diri dalam kelompoknya. Mereka segera mengerjakan tugas sesuai dengan LKPD. (2) Komunikasi antara siswa dan guru terjalin dengan baik. Siswa tidak takut untuk bertanya kepada guru, dan gurupun selalu menanggapi pertanyaan peserta didik dengan baik.

Berdasarkan hasil observasi peneliti dan kolaborator selama proses tindakan pembelajaran dan tes prestasi belajar Matematika siswa, diperoleh gambaran tentang tindakan kelas yang dilaksanakan dalam pertemuan pertama siklus II.

Aspek keberhasilan pelaksanaan tindakan pada pertemuan pertama siklus II adalah: (1) Pembelajaran berjalan dengan lancar dan menarik. Siswa dengan senang melakukan kegiatan memecahkan masalah menentukan skala. (2) Secara umum peserta didik sudah menunujukkan partisipasi aktif dalam proses pembelajaran, walaupun masih memerlukan petunjuk dan bimbingan dari guru. Kelemahan pelaksanaan tindakan pada pertemuan pertama siklus II yaitu ada 2 anak yang masih belum bisa aktif dalam bekerja kelompok.

Kegiatan pembelajaran dilanjutkan pada siklus II pertemuan II. Kegiatan perencanaan 
dilakukan dengan menyusun RPP, alat peraga/ media, Lembar Kerja Peserta Didik, dan Lembar Pengamatan/observasi.

Kegiatan tindakan atau pelaksanaan diawali dengan doa, salam, dan menanyakan kabar serta mengecek kehadiran siswa, menyanyikan lagu Indonesia Raya. mengulas sedikit materi yang telah disampaikan hari sebelumnya serta menyampaikan tujuan pembelajaran.

Kegiatan inti siswa dibagi menjadi 6 kelompok. Masing-masing terdiri atas 4 anak. Kegiatan kelompok diawali dengan membaca permasalahan yang ada pada LKPD, kemudian siswa melakukan kegiatan memecahkan masalah cara menentukan skala sesuai petunjuk pada lembar kerja.

Siswa diberikan LKPD untuk diselesaikan dalam diskusi kelompok. Sebuah kebun berbentuk persegi Panjang, panjang kebun tersebut $12 \mathrm{~cm}$ dan lebarnya $5 \mathrm{~cm}$. skala gambar adalah 1: 5000. Berapa panjang dan lebar kebun sebenarnya?

Penyelesaianya adalah : Skala $=1: 5000=$ 1 per 5000. Panjang taman pada gambar adalah 1 $\mathrm{cm}$. Panjang taman $=$ panjang denah $:$ skala $=12$ : 1 per $500=12 \times 5000=60000$. Jadi panjang taman sebenarnya adalah $60.000 \mathrm{~cm}$ atau $600 \mathrm{~m}$.

Lebar taman pada gambar $=5 \mathrm{~cm}$. lebar taman $=$ Lebar denah : skala $=5: 1$ per $5000=5 \mathrm{x}$ $5000=25.000$. Jadi lebar taman sebenarnya adalah $25.000 \mathrm{~cm}=25 \mathrm{~m}$

Untuk mengetahui keberhasilan pada siklus II, maka dilakukan kemudian siswa mengerjakan soal evaluasi.

Kegiatan pembelajaran diakhiri dengan menyanyikan salah satu lagu daerah untuk menumbuhkan nasionalisme, persatuan, dan toleransi, kemudian doa penutup dan salam.

Observasi pada pertemuan kedua siklus II dilakukan oleh peneliti maupun kolaborator. Saat kegiatan dimulai, anak-anak tampak lebih gembira karena mereka akan melakukan kegiatan menentukan skala. Anak lebih siap mengikuti pembelajaran dari pada siklus sebelumnya

Hasil observasi akifitas guru mendapatkan skor 22 yang berarti nilainya 92\% dalam kategori sangat baik. Pada kegiatan observasi ini diketahui gambaran tentang kelebihan maupun kekurangan selama pelaksanaan kegiatan pembelajaran. Kelebihan yang diperoleh adalah: (1) Guru telah memberikan koreksi berupa umpan balik dari setiap hasil penugasan dari peserta didik. (2) Guru telah memberikan reward bagi peserta didik yang berhasil menyelesaikan penyelesaian masalah dengan baik dan benar. Reward tersebut berupa pujian. Dengan pujian tersebut diharapkan peserta didik menjadi lebih bersemangat dalam mengikuti pembelajaran. (3) Guru telah memberikan arahan tentang pelajaran selanjutnya.

Selain kelebihan tersebut, terdapat kekuarangan yaitu guru belum mampu melibatkan seluruh siswa dalam kegiatan pembelajaran. Masih ada 2 siswa yang belum bisa aktif dalam kegiatan pembelajaran. Mereka baru bisa aktif jika diberikan teguran dari temannya.

Hasil observasi aktifitas siswa mendapatkan skor 22 yang berarti nilainya $92 \%$ atau dalam kategori baik. Pada kegiatan observasi aktifitas siswa ini diketahui gambaran tentang kelebihan maupun kekurangan selama pelaksanaan kegiatan pembelajaran. Kelebihan yang diperoleh adalah (1) Anak-anak sudah siap dengan kegiatan pembelajaran yang akan dilakukan. (2) Semua kelompok dapat menyelesaikan tugas tepat waktu.

Adapun kekurangan yang tampak dari aktivitas peserta didik saat pelaksanaan pembelajaran yaitu belum semua siswa ikut aktif dalam kegiatan pembelajaran. Dalam kegiatan diskusi kelompok, ada anak yang belum aktif dalam kelompoknya.

Kegiatan pembelajaran kedua siklus II ditutup dengan mengerjakan evaluasi. Nilai hasil tes pada siklus II dapat dilihat pada tabel 2 berikut. 


\begin{tabular}{clccc}
\hline No & Nama & Nilai & KKM & Keterangan \\
\hline 1 & AMA & 90 & & Tuntas \\
2 & ADF & 80 & Tuntas \\
3 & AES & 75 & Tuntas \\
4 & DAS & 80 & Tuntas \\
5 & DP & 90 & Tuntas \\
6 & EYP & 75 & Tuntas \\
7 & FAS & 100 & & Tuntas \\
8 & FRM & 70 & & Belum tuntas \\
9 & FBS & 85 & 75 & Tuntas \\
10 & FDES & 90 & Tuntas \\
11 & GG & 90 & & Tuntas \\
12 & GJE & 70 & Belum tuntas \\
13 & HNH & 100 & Tuntas \\
14 & HSD & 100 & Tuntas \\
15 & JH & 80 & Tuntas \\
16 & KS & 90 & Tuntas \\
17 & MSA & 100 & Tuntas \\
18 & MANA & 90 & Tuntas \\
19 & NAU & 75 & Tuntas \\
20 & RDA & 90 & Tuntas \\
21 & RRZGA & 100 & Tuntas \\
22 & SZA & 100 & Tuntas \\
23 & TP & 70 & Belum tuntas \\
24 & YSM & 80 & Tuntas \\
\hline & & &
\end{tabular}

Berdasarkan tabel di atas, dapat diketahui bahwa 21 siswa atau $88 \%$ siswa sudah mencapai KKM atau nilai 75. Hasil ini berarti nilai pada siklus II sudah mencapai terget yang diharapkan, yaitu mencapai minimal $75 \%$

Berdasarkan hasil observasi peneliti dan kolaborator selama proses tindakan pembelajaran dan tes prestasi belajar Matematika siswa, diperoleh gambaran tentang tindakan kelas yang dilaksanakan dalam siklus II. Aspek keberhasilan pelaksanaan tindakan pada pertemuan kedua siklus I adalah siswa menunjukkan sikap antusis dengan berusaha menyelesaikan permasalahan-permasalahan yang diberikan. Siswa juga cukup antusias memanfaatkan media belajar yang telah disediakan.

Persentase prestasi belajar siswa matematika yang telah tuntas sebesar $88 \%$ yaitu sebanyak 21 siswa. Nilai prestasi anak yang belum tuntas sebesar $22 \%$ yaitu sebanyak 3 siswa. Hal ini menunjukkan bahwa persentase peserta didik yang tuntas sudah di atas kriteria keberhasilan yang ditetapkan yaitu $75 \%$ dari jumlah siswa.

\section{Pembahasan}

Berdasarkan data hasil penelitian siklus I dan II tersebut, dapat dilihat bahwa penelitian ini sudah mencapai tujuan yang diharapkan sehingga selesai pada siklus II. Pada setiap pertemuan dilakukan observasi tentang kegiatan pembelajaran dilihat dari aspek guru dan siswa. Pada setiap akhir siklus dilaksanakan tes untuk mengetahui peningkatan prestas belajar matematika siswa. Selanjutnya diadakan refleksi antara guru dan kolabolator untuk mengetahui permasalahan maupun hasil yang didapatkan dari proses pembelajaran tersebut. Hasil refleksi tersebut dijadikan sebagai dasar perbaikan pada siklus berikutnya.

Pada setiap tindakan siklus I maupun II, guru telah menggunakan pendekatan discovery learning. Kegiatan pembelajaran telah dilaksanakan sesuai dengan perencanaan. Dari hasil analisis yang dilakukan bersama kolabolator, pada saat pelaksanaan pembelajaran siklus I guru sudah melaksanakan pembelajaran sesuai dengan rencana pelaksanaan pembelajaran yang telah dibuat. Guru selalu memotivasi peserta didik selama pembelajaran berlangsung agar siswa bersemangat dalam mengikuti kegiatan pembelajaran. Guru juga sudah menggunakan media yang menarik karena media yang digunakan adalah benda sebenarnya.

Selain kelebihan tersebut, terdapat kekuarangan yang dilakukan guru yaitu belum memberikan kesempatan anak berpikir kritis, belum melibatkan seluruh siswa dalam kegiatan pembelajaran, dan tes evaluasi hanya dilakukan pada akhir siklus atau akhir pembelajaran ke-2.

Rerata hasil observasi terhadap kegiatan pembelajaran dapat digambarkan dengan gambar berikut. 


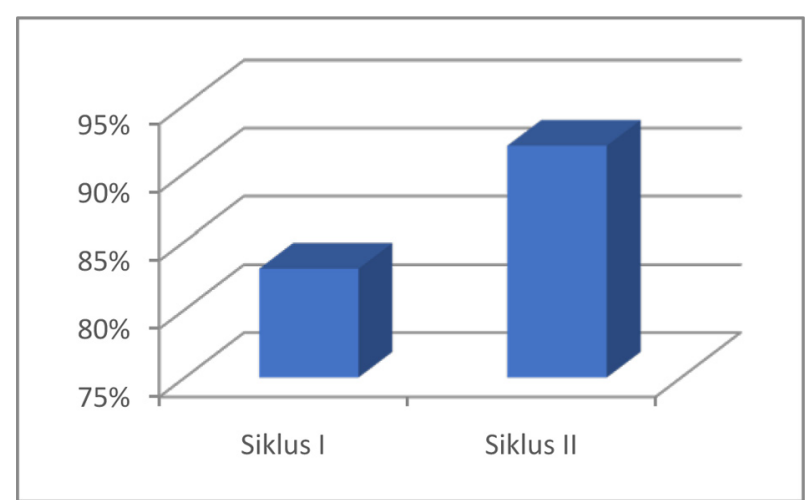

Gambar 1. Pelaksanaan Pembelajaran Dilihat dari Aspek Aktivitas Guru

Berdasarkan gambar 1 tersebut, dapat diketahui bahwa pelaksanaan pembelajaran menggunakan pendekatan discovery learning mengalami peningkatan pada tiap siklusnya. Pada siklus I sebesar $83 \%$ dengan kaegori baik. Sedangkan untuk siklus II naik menjadi $92 \%$ dengan kategori sangat baik.

Keterlaksanaan pembelajaran juga dilihat dari aspek siswa. Persentase hasil observasi kegiatan pembelajaran dilihat dari aspek siswa dapat dilihat pada gambar 2 berikut.

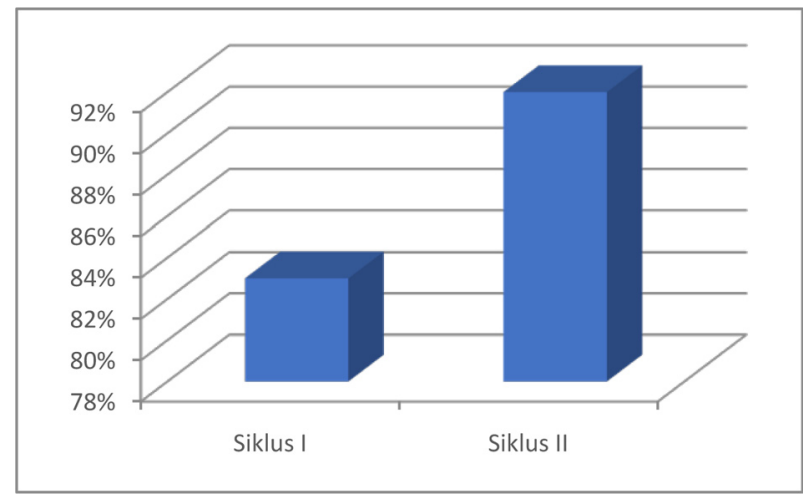

Gambar 2. Pelaksanaan Pembelajaran Dilihat dari Aspek Aktivitas Siswa

Berdasarkan gambar 2 tersebut, dapat diketahui bahwa pelaksanaan pembelajaran menggunakan pendekatan discovery learning dilihat dari aspek siswa mengalami peningkatan pada tiap siklusnya. Pada siklus I sebesar $83 \%$ dengan kategori baik. Sedangkan untuk siklus II naik menjadi $92 \%$ dengan kategori sangat baik.
Dengan demikian dapat disimpulkan bahwa pelaksanaan pembelajaran melalui pendekatan discovery learning terlaksana dengan sangat baik. Kualitas pembelajaran yang disampaikan guru sangat mempengaruhi aktivitas siswa.

Permasalahan di kelas V SD Tulasan adalah rendahnya prestasi belajar Matematika siswa. Data awal diketahui bahwa 50\% siswa memperoleh nilai di bawah KKM atau belum tuntas. Untuk itu, guru harus melakukan inovasi pembelajaran agar pembelajaran dapat mendorong siswa agar lebih aktif sehingga dapat meningkatkan prestasi belajarnya. Dengan ini, dilakukan kegiatan penelitian tindakan melalui pendekatan discovery learning. Kegiatan pembelajaran dalam penelitian ini dilaksanakan selama 2 siklus. Tiap siklus terdiri atas 2 pertemuan. Untuk mengetahui peningkatan prestasi belajar Matematika, maka di akhir tiap siklus dilakukan tes.

Prestasi belajar Matematika dapat dilihat dari ketuntasan dalam memperoleh nilai KKM. Persentase ketuntasan hasil tes terhadap siswa kelas V SD Tulasan dapat dilihat pada gambar 3 berikut.

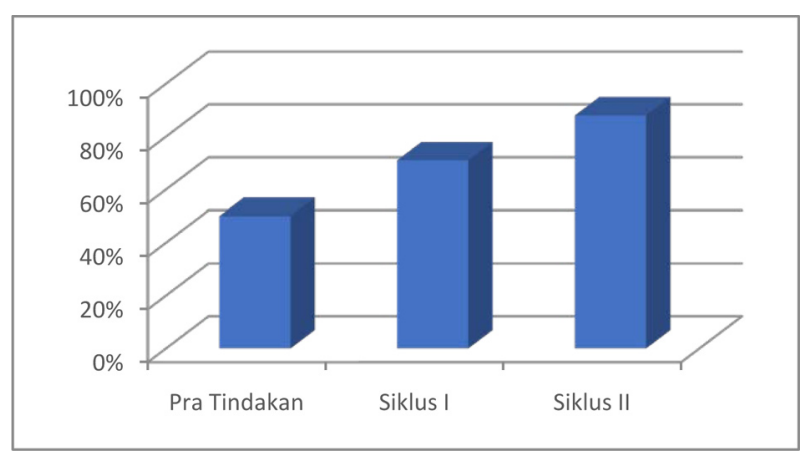

Gambar 3. Peningkatan Prestasi Belajar Matematika Siswa

Berdasarkan gambar 3 tersebut dapat diketahui bahwaketuntasan belajar siswa mengalami peningkatan. Sebelum tindakan, ketuntasan belajar Matematika hanya 50\%. Pada siklus I naik menjadi $71 \%$, sedangkan pada siklus II naik lagi menjadi $88 \%$. Kriteria keberhasilan penelitian yang dilakukan adalah penelitian berhasil jika minimal $75 \%$ siswa telah mendapatkan nilai matematika di atas KKM, yaitu 75 . 


\section{SIMPULAN}

Berdasarkan hasil tindakan yang telah dilakukan dalam dua siklus, serta seluruh pembahasan dan analisis yang telah dilakukan, dapat disimpulkan bahwa pendekatan discovery learning yang diterapkan dalam penelitian tindakan ini dapat meningkatkan prestasi matematika siswa kelas V SD Tulasan.

Hal ini ditunjukkan dengan hasil tes yang dilakukan kepada siswa kelas V setelah mengikuti kegiatan pembelajaran dengan pendekatan discovery learning mengalami peningkatanju juga telah mencapai kriteria keberhasilan yang ditetapkan. Pada tes awal sebelum tindakan perolehan nilai rata-rata 70,83 dengan persentase ketuntasan 50\%. Pada siklus I perolehan nilai rata-rata 79,58 dengan persentase ketuntasan 71\%. Pada siklus II meningkat lagi dengan perolehan nilai rata-rata $85,83 \%$ dengan persentase ketuntasan mencapai $88 \%$.

Kriteria keberhasilan penelitian yang ditetapkan adalah penelitian berhasil jika minimal $75 \%$ siswa telah mendapatkan nilai matematika di atas KKM atau tuntas. Dengan demikian dapat disimpulkan bahwa penelitian ini telah berhasil karena telah mencapai target yang ditentukan.

Langkah-langkah penerapan pendekatan discovery learning yang dapat meningkatkan prestasi belajar siswa kelas V SD Tulasan adalah pertama guru memberikan motivasi kepada siswa untuk menfokuskan perhatian. Kedua yaitu mengkomunikasikan tujuan pembelajaran. Ketiga memulai pelajaran dengan mengajukan masalah sesuai dengan pengalaman dan tingkat pengetahuannya. Keempat yaitu Siswa mengembangkan atau menciptakan model-model simbolik secara informal terhadap persoalan/ masalah yang diajukan.

\section{DAFTAR PUSTAKA}

Sembiring, R., Hoogland, K., Dolk, M.(2010). A Decade of PMRI in Indonesia. Bandung:Utrecht

Hosnan, M. 2014. Pendekatan Saintifik dan Kontekstual dalam Pembelajaran Abad 21. Bogor: Ghalia Indonesia.
Ariyana, Yoki,dkk. 2018. Buku Pegangan Pengembangan Berorientasi pada keterampilan Berpikir Tingkat Tinggi. Jakarta: Direktorat Jenderal Guru dan Tenaga Kependidikan, Kemdikbud.

Daryanto. Pendekatan Pembelajaran Saintifik Kurikulum 2013. Yogyakarta: Gava Media.

Suprihatiningrum, Jamil. 2013. Strategi Pembelajaran: Teori dan Aplikasi. Arruzz media: Jogjakarta

Kurniasih, Imas dan Berlin Sani. 2014. Implementasi Kurikulum 2013 Konsep dan Penerapan. Surabaya: Kata Pena.

https://www.kajianpustaka.com/2017/09/metodepembelajaran-penemuan-discoverylearning.html. Diakses tanggal 10 Februari 2020 